\title{
Tagore and Naipaul on Indian and European Civilisations: Patriotic and Biassed Views Changed their Perspectives
}

\author{
Aju Mukhopadhyay \\ Poet, Critic and Author \\ India \\ ajum24@gmail.com
}

V. S. Naipaul was writer of Indian origin writer settled in Great Britain and Rabindranath Tagore was Bengali writer born and brought up in India. Both were Nobel Laureates in Literature. Based on their overall behavior and treatment with the colonized people, Tagore a patriot to the core, saw and judged the foreign colonisers from his Indian patriotic point of view. He realised how and why they sucked India for their own benefit to the utter neglect of Indians. But Naipaul's ancestors migrated perhaps under compulsion to the Caribbean islands where Naipaul was born (Chaguanas, Trinidad and Tobagos). He settled in England and stayed put there for the major part of his life. Compared to his background Britain was new found paradise for him. Ambitious, he studied English and was imbued in their culture. He wrote as if Britain was more than his birth land. He was awarded Nobel Prize as a British, a European. From his perspective he was not only indebted but deeply moved to love that country and continent. His name and fame spread from there. India had nothing to do about it except his Indian origin background taking the clue from his ancestors. He had some tilt towards India nothing of it remained when India was compared to Britan or Europe. He was obliged to see the world 
through their spectacles. His ideas and favour for Britain and Europe was generated by his position and interest in life. Judged Neutrally it was a biased view.

Throughout his life Rabindranath Tagore was a patriot, a nationalist and above all, he was a humanist. He wished Indian freedom and sometimes actively participated in the freedom movement; like taking part in movements against partition of Bengal, presiding over the political party meetings, singing songs in congress sessions, felicitating Aurobindo Ghose, a freedom fighter and welcoming Subhas Chandra Bose decades after it, to take the leadership of the country. He had long standing relationship with M. K. Gandhi, C. R. Das, Jawaharlal Nehru and other Indian leaders of the time. He was never in favour of terrorism nor was he a nonviolent of the Gandhian brand. The primary force in his life was love for the God and from it emanated his love for the country and humanity. He was a mystic poet yet one of the most ardent rationalists of his time who always sought peace for the people of the world.

In his famous speech in Shantiniketan, later published titled Crisis in Civilization (delivered in his presence when he was an octogenarian poet in 1941, a few months before his departure from the world) the poet gave an account in detail as to how his ardent love for English literature remained but of lesser interest to him then because of the change of his heart for the English people in degrees which transformed gradually all his good feelings and ideas about them into grievance and grief. He was shocked at their imperialist pride and change of character though he admitted frankly that there were great souls among them still who remained true to their character and behavior as he had seen them in his early youth. Excerpts from his speech would bring out the positions as he observed which were laid with reasoned high prose coupled with poetic exuberance from time to time. It tells about the gradual loss of poet's faith 
in Western civilization and rising hope for the oriental nations, hope for them to rise up to lead the human race to a new height.

The scope of learning and enquiry was limited in the days of his childhood and youth. The educated had recourse to English language and literature. He opined, "It was mainly through their mighty literature that we formed our ideas with regard to these newcomers to our Indian shores. . . England at that time provided a shelter to all those who had to flee from persecution in their own country... . I was impressed by this evidence of liberal humanity in the character of the English and thus I was led to set them on the pedestal of my highest respect. This generosity in their national character had not yet been vitiated by imperialist pride." (Tagore V.3 722)

He admitted that English literature which had nourished the Indian mind in the past still conveyed its deep resonance in the recesses of their heart. Trying to define what could be the equivalent of the English word civilization, he referred to Sadachar or proper conduct which was in vogue in Brahmavarta, a place bound by Saraswati and Drisadvati rivers, as defined by the sage Manu, but admitted that such behavours of the colonizers were degenerated steadily into socialized tyranny. Under the circumstance of prevailing narrowness and tyranny, "We accepted the ideal of 'civilization' as represented by the English term." (Tagore V.3 723)

"Then came the parting of ways accompanied with a painful feeing of disillusion when I began increasingly to discover how easily those who accepted the highest truths of civilization disowned them with impunity whenever questions of national self-interest were involved ....

"I had to snatch myself away from the mere appreciation of literature . . the sight of dire poverty of Indian masses rent my heart. Rudely shaken out of my dreams, I began to realize that perhaps in no other modern state was there such hopeless dearth of the most elementary 
needs of existence. And yet it was this country whose resources had fed for so long the wealth and magnificence of the British people. . . I could never have remotely imagined that the great ideals of humanity would end in such ruthless travesty. . . .

"That mastery over the machine, by which the British have consolidated their sovereignty over their vast Empire, has been kept a sealed book, to which due access has been denied to this helpless country. And all the time before our very eyes Japan has been transforming herself into a mighty and prosperous nation. I have seen with my own eyes the admirable use to which Japan has put in her own country the fruits of progress. I have also been privileged to witness, while in Moscow, the unsparing energy with which Russia has tried to fight disease and illiteracy, and has succeeded in liquidating ignorance and poverty, wiping off the humiliation from the face of a vast continent. Her civilization is free from all invidious distinction between one class and another .... It provided no scope for unseemly conflict of religious difference nor set one community against another by unbalanced distribution of political favours. That I consider a truly civilized administration which impartially serves the common interests of the people.

"When I look upon my own country and see a very highly evolved and intellectual people drifting into the disorder of barbarism, I cannot help contrasting the two systems of governments, one based on co-operation and the other on exploitation . .." (Tagore V.3 723724)

In the recent past towards the end of his life's journey the poet had visited more countries like Iran which too had been trying to prosper with self sufficiency. So our neighbouring Afghanistan too had scope to prosper without any foreign intervention, he observed. 
"Thus while these other countries were marching ahead, India, smothered under the dead weight of British administration, lay static in her utter helplessness. Another great and ancient civilization for whose recent tragic history the British cannot disclaim responsibility, is China. To serve their own national profit the British first doped her people with opium and then appropriated a portion of her territory. ... While Japan was quietly devouring North China, her act of wanton aggression was ignored as a minor incident by the veterans of British diplomacy. We have also witnessed from this distance how actively the British statesmen acquiesced in the destruction of the Spanish Republic.” (Tagore V.3 724)

While admiring the British spirit behind some individual's heroic action for the Spanish cause, the poet with anguish said again, "Such acts of heroism reminded me over again of the true English spirit to which in those early days I had given my full faith, and made me wonder how imperialist greed could bring about so ugly a transformation in the character of so great a race.

"Such is the tragic tale of the gradual loss of my faith in the claims of the European nations to civilization. In India the misfortune of being governed by a foreign race is daily brought home to us not only in the callous neglect of such minimum necessities of life as adequate provision for food, clothing, educational and medical facilities for the people, but in an even unhappier form in the way the people have been divided among themselves. The pity of it is that the blame is laid at the door of our own society. So frightful a culmination of the history of our people would never have been possible, but for the encouragement it has received from secret influences emanating from high places.” (Tagore V.3 725)

Speaking of the glorious character of some English men he knew, like his friend C. F. Andrews who wished and wrote openly about the rationale of Indian independence, he said that 
had he not known them his despair at the prospect of the modern civilization would remain unrelieved. He continued,

"In the meanwhile the demon of barbarity has given up all pretence and has emerged with unconcealed fangs, ready to tear up humanity in an orgy of devastation. From one end of the world to the other the poisonous fumes of hatred darken the atmosphere. The spirit of violence which perhaps lay dormant in the psychology of the West, has at last roused itself and desecrates the spirit of Man.” (Tagore V.3 726)

It will be quite germane here to refer to V. S. Naipaul's visit to Calcutta twice during the second half of twentieth century when he visited India during 1962, 1975-76 and 1988, and his ideas and opinions about Calcutta, the dead city, as he said in his famous book, India: A Million Mutinies Now. While narrating his story of Calcutta the writer turned his gaze towards Tagore's above speech and tried to compare Tagore's vision with his own, taking the famous speech as the old man's melancholic grumbling which failed to see the real perspective of the situation, which failed to appreciate the grand spirit of the English and Europe while failing to see the real state of Calcutta and failing to see why Calcutta had attained such a ruinous and dying condition from which a recovery was next to impossible.

Referring to Chidananda Dasgupta, his companion, Naipaul writes, "On that visit Chidananda heard Tagore, nearly eighty, deliver a talk in the Shantiniketan temple on 'Crisis in Civilization'. In that talk- a famous talk, published a few months after Chidananda heard itTagore said he had always believed that 'the springs of civilization' would come out of 'the heart of Europe'. Now with the War and the coming cataclysm, he could no longer have the faith. But he couldn't lose faith in man; that would be a sin. He lived now in the hope that the dawn would come from the 
East, 'where the sun rises', and that the saviour would be born 'in our midst, in this povertyshamed hovel which is India.'

"It was an old man's melancholy farewell to the world. Five years later the war was over. Europe began to heal; in the second half of the century Europe and the West were to be stronger and more creative and more influential than they had ever been. The calamity Tagore hadn't foreseen was the calamity that was to come to Calcutta.

"In 1946 there were the Hindu-Muslim massacres. They marked the beginning of the end for the city. The next year India was independent, but partitioned. Bengal was divided. A large Hindu refugee population came and camped in Calcutta; and Calcutta, without a hundredth part of the resilience of Europe, never really recovered.” (Mutinies 349-50)

Excuse me! Such resilience of Europe must be as Sir Naipaul had been staying there from the beginning of the second half of the last century and inspired by what he received in life based on his stay and activities there. Apparently he was not aware of nor could guess the coming plight and predicament that are over the Europe in recent past; economic fundamentals are horrible, stock prices have fallen so the value of Euro. Unemployment is at its highest in Greece and Spain. Prices of real estate are falling in France. Corruption is eating into its civilized fabric as it does in India. In recent past, people from Greece were fleeing to safer areas. And the latest controversy of Brexit initiated by British Prime Minister, Theresa May, is raging in Europe. European leaders have expressed doubt about its success, some have advanced precaution that there will be heavy fall of Britain's financial progress. The crisis in civilization continues with continuous interference by the mightier nations, including the European ones, in the affairs of weaker nations, wreaking havoc in the life of the other people. 
Rise and fall of nations and civilizations are usual in the course of time. Tagore never used the words, "in this poverty-shamed hovel which is India," for he was not an outsider seeking fame by criticising India. He was not nearing eighty then; it was his birthday completing eighty. The speech was read by Kshiti Mohan Sen in the presence of the poet, print copy of which was distributed then and there. Noting this much of lacuna in the narrator's introduction to the speech, let us read the relevant part of the speech to know the position as Tagore had understood and Naipaul interpreted later.

“Today I complete eighty years of my life. As I look back .... I am struck by the change that has taken place ... a change that carries within it a cause of profound tragedy.

"The wheel of Fate will someday compel the English to give up their Indian empire. But what kind of India will they leave behind, what stark misery? When the stream of their centuries' administration runs dry at last, what a waste of mud and filth they will leave behind them! I had at one time believed that the springs of civilization would issue out of the heart of Europe. But today when I am about to quit the world that faith has gone bankrupt altogether.

“As I look around I see the crumbling ruins of a proud civilization strewn like a vast heap of futility .... And yet I shall not commit the grievous sin of losing faith in Man. I would rather look forward to the opening of a new chapter in his history .... Perhaps that dawn will come when unvanquished Man will retrace his path of conquest, despite all barriers, to win back his lost human heritage.

"Today we witness the perils which attend on the insolence of might; one day shall be borne out the full truth of what the sages have proclaimed:

'By unrighteousness man prospers, gains what appears desirable, conquers enemies, but perishes at the root."' (Tagore V.3 722-26) 
Though during his teens and youth the poet visited England, lived as paying guest also with some English lady, his family had good relationship with the British Royals and the English in general from the time of his grandfather, legendary Prince Dwarakanath Tagore who was in close relationship with the British, including their high ups. He lived there too for some time. But the complication of relationship of a colonized country with the coloniser, with all practical sides of it, gradually became a matter of concern for the poet who loved his Motherland more than English literature and more than many adorable things in life like personal honour and reputation. The glimpses of his mind may be guessed from few lines of a poem written much earlier, on the last day of the nineteenth century, titled, The Sunset of the Century, when the poet was not even in his forties.

The crimson glow of light on the horizon is not the light of thy dawn of peace, my Motherland,

It is the glimmer of the funeral pyre burning to ashes the vast flesh, - the selflove of the Nation,- dead under its own excess. Thy morning waits behind the patient dark of the East, Meek and silent. Keep watch, India.

Be not ashamed, my brothers, to stand before the proud and the powerful With your white robe of simpleness.

And know that what is huge is not great and pride is not everlasting. 
It was long back that Tagore had thrown the knighthood conferred on him upon the faces of those unrighteous men who perpetrated the crime at Jallianwalla Bagh on 13.4.1919. Tagore with his Himalayan wisdom could easily foresee the departure of the English more than six years before their compulsory exit. He not only saw what the colonizers were leaving behind but also what was at hand but the great famine of Bengal which happened in 1942-43. It was artificially created by creating food scarcity by the colonizers who were afraid of the entry of Japan with Subhas Chandra Bose at its head during the Second World War, as a war preparation, reserving food for the soldiers. They played a guerrilla tactics of creating famished Bengal and Calcutta lest they would venture to help the incoming force of Subhas Chandra Bose. Calcutta received the shock of artificial famine. The Hindu-Muslim strife, as was always rife under the reactionary provincial government, helped by the foreign rulers, was not only foreseen by Tagore but foretasted three months before he left the world, as recorded in the speech above. He always protested against the wrong doers. When Miss E. Rathbone, a member of British parliament, wrote an open letter to Indians trying to bring shame on them clearly stating that Indians owed all their developments to the English rulers but did not join to help them during the Second World War, Tagore with his frail body responded by writing an open befitting letter which was published in almost all Indian dailies in English on 5.6.1941.

If the writer Sir Vidya honestly felt pride at the capacity and resilience of Europe, he should have realised that Calcutta, flooded with people from the neighbouring countries and other provinces for hundreds of years for business and various occupations, accepting all the refugees from time to time for the deliberate partition of the country by the leaders whom it did not affect directly, tortured for becoming the first city of revolutionaries against the colonial rulers and suffering from many day-to-day calamities including the death-romance of 
communist adventurism, has still been living with ever more population, crossing 140 crore with improved metro rail system, with its hinterland expanded to accommodate additional people in different areas adjacent, including the Salt Lake, as it was growing when the writer was making his diary notes. Kolkata has an estimated population of $\mathbf{4 . 6}$ million. The largest urban area that includes the suburbs has a population of more than $\mathbf{1 4 . 3}$ million, which makes it India's 3rd most populous metropolitan area.1

In spite of all political dirtiness and mixture of heterogeneous culture Kolkata has more resilience, it seems, than many other cities. It survives though it is undergoing different changes including demographic changes with roads full of petty businessmen, labourers, party workers and idlers; the original dwellers of the city having gone and going out of it regularly.

Almost half of Naipaul's book covers the story of Calcutta which the writer has often mentioned as "Beginning to die" or "A dead city". Though Calcutta is victim of political plays; its average people cannot be said to be very ideal, the health of Calcutta is environmentally strained we strongly believe that it will very well survive and prosper even undergoing changes. It may change its character but will surely remain with verve till history wishes it to remain and for that matter time and perspective have to be considered in respect of Kolkata as of all other cities and civilizations of the world. Kolkata alone cannot go down while its neighbours would remain. Sir Vidya could not realise the reasons for the devastating situation in Calcutta as he had seen and commented upon and of its neighbourhood at that time as Tagore had understood. The foreboding thought and anxiety about the Motherland was always with Tagore as he was growing up to adulthood; Crisis of Civilization was the full blooming of Poet Rabindranath Tagore's ideas about India and its relationship with the colonizers at his ripe age. 


\section{Notes}

World Population Review as it the Net. http://worldpopulationreview.com/worldcities/kolkatapopulation/ 


\section{References}

The English Writings of Rabindranath Tagore. New Delhi; Sahitya Akademi. V.3. Reprint2002.

V. S. Naipaul. India: A Million Mutinies Now. USA: Penguin Books. 1992. Print. Rabindranath Tagore. V.2. Reprint-2004 